After Civil War 
NATIONAL AND ETHNIC CONFLICT

IN THE TWENTY-FIRST CENTURY

Brendan O'Leary, Series Editor

A complete list of books in the series is available from the publisher. 


\section{After Civil War}

Division, Reconstruction, and Reconciliation in Contemporary Europe

Edited by

\section{Bill Kissane}

\section{PENN}

UNIVERSITY OF PENNSYLVANIA PRESS

PHILADELPHIA 
Copyright (C) 2015 University of Pennsylvania Press

All rights reserved. Except for brief quotations used for purposes of review or scholarly citation, none of this book may be reproduced in any form by any means without written permission from the publisher.

Published by

University of Pennsylvania Press

Philadelphia, Pennsylvania 19104-4112

Printed in the United States of America

on acid-free paper

1098876654321

Library of Congress Cataloging-in-Publication Data

After civil war : division, reconstruction, and reconciliation in contemporary Europe / edited by Bill Kissane. -1 st ed.

p. cm.-(National and ethnic conflict in the twenty-first century)

Includes bibliographical references and index.

ISBN 978-0-8122-4652-0 (hardcover : alk. paper)

1. Europe-History-20th century. 2. Postwar

reconstruction-Europe-History-20th century-Case studies. 3. Civil war-Europe-History-20th century-Case studies. 4. ReconciliationPolitical aspects-Europe-History-20th century-Case studies.

5. Nationalism-Europe-History-20th century-Case studies. I. Kissane, Bill.

II. Series: National and ethnic conflict in the 21 st century.

D424.A35 2015

303.6'90940904-dc23 
These fragments I have shored against my ruins.

T. S. Eliot, The Waste Land, 1922 
